EFFECT OF HYBRID, PLANTING DATES AND HARVESTING DATES ON YIELD, QUALITY, AND STORABILITY OF BABY CORN CROP.

\author{
Shehata, S.A.*, Manal M. Attia ** and Mohamed,M.E** \\ * Faculty of Agriculture, Cairo University, Giza, Egypt \\ ** Postharvest and Handling of Vegetable Crops Department.Horticulture Research \\ Institute. Agriculture Research Center, Giza, Egypt.
}

\begin{abstract}
Field and storage experiments were conducted during 2014 and 2015 seasons. The field experiment was carried out at the experimental station of the Faculty of Agriculture, Cairo university ,Giza, Governorate Seeds of field corn , 352 and 323 triple hybrids were sown $1^{\text {st }}$ May, $1^{\text {st }}$ June and $1^{\text {st }}$ July and harvested 1, 2 and 3 days after silk emergence. Ears from the previous experiment (three planting dates and three harvesting dates) were stored at $5{ }^{\circ} \mathrm{C}$ and $90-95 \%$ relative humidity for 15 days to investigate the effect of hybrid, planting date and harvesting date on accumulated heat units growing degree days (GDD), vegetative growth, ear characters, yield and storability of baby corn ears.

Results showed that baby corn plants needs 1747.6, 1694.2 (GDD) for 323 hybrid and 1822.8 and 1745.4 for 353 hybrid to reach the optimum harvest stage of ears with the best quality ( 2 days after siliking) for the first and second seasons, respectively. Results revealed that 353 hybrid had significantly increment in vegetative growth parameters and produced higher total yield and its components per Fadden than those obtained by 323 hybrid. 353 hybrid planted on $1{ }^{\text {st }}$ May and $1{ }^{\text {st }}$ June had the highest vegetative growth and total yield and its components (ear weight and number of cobs / $\mathrm{m}^{2}$ while 323 hybrid planted in $1^{\text {st }}$ June was the lowest ones in these characters. The best value of ear length and ear diameter concerning to marketability were obtained from 353 hybrid which planted in $1{ }^{\text {st }}$ May and harvested after 2 days from silk emergence being about $9.32 \mathrm{~cm}$ and $10.38 \mathrm{~mm}$, respectively.

For storability, General Appearance (GA) in ears obtained from planting on $1^{\text {st }}$ May and harvested after 2 days from silk emergence did not exhibit any changes in their appearance till the end of storage period (15 days).,also gave the lowest weight loss \%, had highest $\mathrm{L}$ value ( indicating lighter color) and $\mathrm{b}$ value ( indicating light yellowing) and maintained total sugars during storage.
\end{abstract}

\title{
INTRODUCTION
}

Baby corn or young - ear corn (Zea mays L.) is widely cultivated thought the world. Baby corn may be produced from sweet corn or field corn, this product is very green ear, which is harvested and consumed in pollination

Fayoum J. Agric. Res. \& Dev., Vol. 30, No.1, January, 2016 
stage (1 to 3 days after silk emergence) (wang $\boldsymbol{e t}$ al., 2010). It is the entire young cob, which has high nutritional value such as vitamins $\mathrm{b}$ and $\mathrm{C}$, fibers and carotenoids. Baby corn has a cultivation market especially in United Kingdom and became an important vegetable for exportation.

The productivity and quality of baby corn or sweet corn ears depend upon many factors such as climate, planting date, harvesting date, number of ears, husk weight, cob weight and the storage time after harvest (Rahmani, et al.,2009, Kheibari et al., 2014, Attia, 2006, Wang et al.,2010)

During the last several decades there were increases in average air temperatures have been reported and associated affects on climate have been debated worldwide in a variety of forums. Due to its importance around the globe, agriculture was one of the first sector to be studied in terms of potential impacts of climate change (Adms et al., 1990).

Exposure to elevated temperatures can cause morphological, anatomical, physiological and biochemical changes in plant tissue, and, as a consequence, can affect growth and development of different plant organs. These events can cause drastic reductions in commercial yield. Fruit and vegetable growth and development are influenced by different environmental factors ( Bindi et al.,1996).

Lass et al., (1993) recognized that basting plant development rate on heat - unit accumulation is preferable to using growth days. Also observed a high correlation between accumulated mean temperature and corn growth. Nielsen,(2012) found that the growth and development of corn are strongly development on temperature. Corn develops faster when temperatures are warmer $\left(27-32^{\circ} \mathrm{C}\right)$ and more slowly when temperatures are cooler $\left(13{ }^{\circ} \mathrm{C}\right)$.

The most effective factor in producing baby corn is suitable variety. Accordingly, the most important criteria for the selection of suitable varieties are early maturity, prolificacy (more number of cobs)and synchronized ear emergence ( Kumar and Kallo,2000). Even though there may be specific traits requirements that could make a variety suitable for baby corn production (Kheibari et al., 2014). Some regular varities of field corn, sweet corn, sugary enhanced sweet corn production (Miles et al., 1999).

The investigation associated with effect of planting date on baby corn yield (Rahmani et al., 2009) found that different planting dates had significantly effects on agronomic traits such as plant height, ear weight. number of leaves above ear, stem diameter, ear length, ear diameter, unhusked and husked baby corn yield. Although revealed that the optimum planting date of baby corn in Iran was 14 June. In another experiment, Oktem, (2004) found that optimal sowing dates of sweet corn could be from June 25 to July 25 in Turkey region.

For harvesting date (El- Bassiouny et al.,(2003) found that baby corn ears at silking where marketability when ears reached $(8-11 \mathrm{~cm})$ in length and

Fayoum J. Agric. Res. \& Dev., Vol. 30, No.1, January, 2016 
EFFECT OF HYBRID, PLANTING DATES AND HARVESTING... 95

$(1.2-1.8 \mathrm{~cm})$ in diameter also who found that harvest ears at one day after silking significantly produced the highest unhusked ears yield, followed by 2 days after silking were For storability, several studies were done to determine the physical and chemical changes in baby corn ears during storage period (Attia et al., (2011) found that quality parameters of baby corn ears which include general appearance and total sugars were decreased during storage while weight loss percentage was increased with the prolongation of the storage period. Also, data revealed that there was a significant decrease in L and $b$ values of baby corn ears during storage.

The objective of this work is studying the effect of accumulated heat units, hybrid, planting date, harvesting date on vegetative growth, yield and storability of baby corn ears.

\section{MATERIALS \&METHODS}

\section{Two experiments were conducted}

\section{Field experiment:}

The field experiment was carried out at the experimental station of the Faculty of Agriculture, Cairo university ,Giza, Governorate, during the two succession seasons of 2014 and 2015. Seeds of field corn (Zea mays L.) 352 triple hybrid (yellow color) and 323 triple hybrid (white color) were sown at three planting date at $1^{\text {st }}$ May, $1^{\text {st }}$ June and $1^{\text {st }}$ July in the two seasons. Normal cultural practices were carried out whenever it was needed according to the recommendations of Ministry of Agriculture. Young ear corn, were harvested at three harvesting date (one day after silk emergence, 2 and 3 days). The plot area was $7.2 \mathrm{~m}^{2}$, every plot consisted of 3 rows, each of $3 \mathrm{~m}$ long, $80 \mathrm{~cm}$ width, with $10 \mathrm{~cm}$ between plants. Complete block design in three replicates was adopted.

The data were recorded as follow:

1) Number of days from sowing to harvest

2) Accumulated heat units (growing degree days) or GDD are calculated by determination the mean daily temperature and subtracting it from the base temperature needed for growth of the organism. thermal (heat) unit calculations were based on daily air temperature maximums and minimum taken from Dokki weather station (the nearest weather station to the sowing location) : and calculated as follow equation:

$\mathrm{GDD}=\mathrm{T} \max +\mathrm{T} \min ) / 2-\mathrm{T}$ base $\left(10^{\circ} \mathrm{C}\right)$ Nielsen (2012).

3) A random sample of five plants from each replicate were taken at harvest time to investigate growth parameters recorded for the two hybrids and planting dates i.e. plant weight $(\mathrm{gm})$, plant height $(\mathrm{cm})$, number of leaves and stem diameter $(\mathrm{cm})$.

4) Ear characteristics

A random sample of 10 ears in each replicate was taken at harvest and examined for following characters recorded for the two hybrids and planting

Fayoum J. Agric. Res. \& Dev., Vol. 30, No.1, January, 2016 
Shehata, S.A. et al.,

dates and harvesting dates unhusked and husked ear weight (gm), ear length $(\mathrm{cm})$ and ear diameter $(\mathrm{cm})$

5) Total yield and its components include number of ears $/ \mathrm{m}^{2}$ for husked and unhusked total yield (gm per $\mathrm{m}^{2}$ ) and ton per feddan).

\section{Storage experiment:}

Baby corn ears were harvested from previous experiment (three planting dates and three harvesting dates), at the proper stage of marketing, then transported to laboratory of Handling of Vegetable Crops Department, Horticulture Research Institute, at Giza Governorate. Husks and silks were removed manually and uniform ears in size, color and free from injury were selected. Twelve experimental units were prepared for each treatment. Each replicate consisted of 5-6 ears and placed in polystyrene tray (Teckpack NAIROP, $5 * 70$ inch PET (Italy) and over wrapped with stretch film $(0.09 \mu \mathrm{c})$.. All treatments were stored at $5{ }^{\circ} \mathrm{C}$ and $90-95 \%$ relative humidity for 15 days. A complete randomized design was adapted. Three replicates from each treatment were taken at random and examined at 5 days intervals (at the day of $0,5,10$ and 15) for the following properties

1. Weight loss percentage was estimated according to the following equation:

Weight loss $\%=$ initial fruit weight - fruit weight at sampling date / initial fruit weight $* 100$.

2. General appearance (GA) was evaluated using scale from 9 to 1 , where $9=$ excellent, $7=$ good, $5=$ fair, $3=$ poor, $1=$ unusable, and cobs rating below 5 were considered unmarketable.

3. Color $\mathrm{L}$ and $\mathrm{b}$ were evaluated by a color difference meter (Minolta CR200) to measure the $\mathrm{L}$ and $\mathrm{b}$ values.

4. Total sugars were measured according to Somogyi (1952) and Nelson (1974).

Complete randomized design in three replicates was adopted.

Combined analysis for each trait was calculated over the two years, before calculating the combined analysis, a test for homogeneity of error squares for the two years was done as outlined by Senedecor and Cochran (1981).

\section{RESULTS AND DISSICUTION}

Heat units accumulation (growing degree days (GDD) and its relation to the number of days to harvest:

Plants need available growing degree days, taking them from the daily temperature to grow and develop. Plants take their needs from temperature by accumulation from planting till harvest.

The obtained data (Table 1) indicated that baby corn plants needs 1747.6 , 1694.2 growing degree days for 323 hybrid and 1822.8 and 1745.4 for 353 hybrid to reach the optimum harvest stage of ears with the best quality standard ( 2 days after siliking) for the first and second seasons respectively, similar results were found with those obtained by Attia (2006). The growing degree days were increased by increasing the period from silking to harvest. This information helps in determination and forecasting harvest date in planting seasons.

Fayoum J. Agric. Res. \& Dev., Vol. 30, No.1, January, 2016 
EFFECT OF HYBRID, PLANTING DATES AND HARVESTING.... 97

Also data in Table (1) revealed that plants cultivated on $1^{\text {st }}$ July gave the early yield after 62 and 63 days from sowing in the first and second season respectively, early by 4 to 5 days compared to $1^{\text {st }}$ June and $1^{\text {st }}$ May, this results may be due to that the rate of development increases with rising temperature until it reaches a plateau at some optimum temperature $\left(10{ }^{\circ} \mathrm{C}\right)$. Similar results were found with those obtained by Lance (2003).

Table (1): Effect of hybrid, sowind date and harvest date on number of days to harvest and accumulated GDD of baby corn crop.

\begin{tabular}{|c|c|c|c|c|c|c|c|}
\hline \multirow{2}{*}{$\begin{array}{c}\text { planting } \\
\text { date (PD) }\end{array}$} & \multirow{2}{*}{$\begin{array}{c}\text { harvest } \\
\text { date } \\
\text { (HD) }\end{array}$} & \multicolumn{2}{|c|}{ No. of days to harvest } & \multirow[b]{2}{*}{ MEAN } & \multicolumn{2}{|c|}{ accumulated GDD } & \multirow[b]{2}{*}{ MEAN } \\
\hline & & 323 hybrid & 353 hybrid & & $\begin{array}{c}323 \\
\text { hybrid }\end{array}$ & $\begin{array}{c}353 \\
\text { hybrid }\end{array}$ & \\
\hline \multicolumn{8}{|c|}{2014} \\
\hline \multirow{3}{*}{$1^{\text {st }}$ May } & $1 \mathrm{DAS}$ & 67.0 & \begin{tabular}{|c|}
66.0 \\
\end{tabular} & 66.5 & 1835.3 & 1807.0 & 1821.2 \\
\hline & 2 DAS & 68.0 & 67.0 & 67.5 & 1864.5 & 1835.3 & 1849.9 \\
\hline & 3 DAS & 69.0 & 68.0 & 68.5 & 1892.6 & 1892.6 & 1892.6 \\
\hline \multicolumn{2}{|c|}{ mean } & 68.0 & 67.0 & 67.5 & 1864.1 & 1845.0 & 1854.6 \\
\hline \multirow{3}{*}{$1^{\text {st }}$ June } & $1 \mathrm{DAS}$ & 65.0 & 66.0 & 65.5 & 1750.0 & 1807.0 & 1778.5 \\
\hline & 2 DAS & 66.0 & 67.0 & 66.5 & 1770.8 & 1835.3 & 1803.1 \\
\hline & 3 DAS & 67.0 & 68.0 & 67.5 & 1807.0 & 1892.6 & 1849.8 \\
\hline \multicolumn{2}{|c|}{ mean } & 66.0 & 67.0 & 66.5 & 1775.9 & 1845.0 & 1810.5 \\
\hline \multirow{3}{*}{$1^{\text {st }}$ July } & $1 \mathrm{DAS}$ & 58.0 & 64.0 & 61.0 & 1570.6 & 1750.0 & 1660.3 \\
\hline & $2 \mathrm{DAS}$ & 59.0 & 65.0 & 62.0 & 1603.9 & 1778.8 & 1691.4 \\
\hline & 3 DAS & 60.0 & 66.0 & 63.0 & 1634.0 & 1807.0 & 1720.5 \\
\hline \multicolumn{2}{|c|}{ mean } & 59.0 & 65.0 & 62.0 & 1602.8 & 1778.6 & 1690.7 \\
\hline \multirow[t]{3}{*}{ mean HD } & 1 DAS & 63.3 & 65.3 & 64.3 & 1135.3 & 1185.7 & 1160.5 \\
\hline & 2 DAS & 64.3 & 66.3 & 65.3 & 1746.4 & 1816.5 & 1781.4 \\
\hline & 3 DAS & 65.3 & 67.3 & 66.3 & 1175.5 & 1233.2 & 1204.4 \\
\hline \multicolumn{2}{|c|}{ mean $\mathrm{H}$} & 64.3 & 66.3 & 65.3 & 1747.6 & 1822.8 & 1785.2 \\
\hline \multicolumn{8}{|c|}{2015} \\
\hline \multirow{3}{*}{$1^{\text {st }}$ May } & 1 & 68.0 & 67.0 & 67.5 & 1766.0 & 1739.1 & 1752.6 \\
\hline & 2 & 69.0 & 68.0 & 68.5 & 1793.2 & 1766.0 & 1779.6 \\
\hline & 3 & 70.0 & 69.0 & 69.5 & 1822.0 & 1793.2 & 1807.6 \\
\hline \multicolumn{2}{|c|}{ mean } & 69.0 & 68.0 & 68.5 & 1793.7 & 1766.1 & 1779.9 \\
\hline \multirow{3}{*}{$1^{\text {st }}$ June } & 1 & 66.0 & 67.0 & 66.5 & 1711.2 & 1739.1 & 1725.2 \\
\hline & 2 & 67.0 & 68.0 & 67.5 & 1739.1 & 1766.0 & 1752.6 \\
\hline & 3 & 68.0 & 69.0 & 68.5 & 1766.0 & 1793.2 & 1779.6 \\
\hline \multicolumn{2}{|c|}{ mean } & 67.0 & 68.0 & 67.5 & 1738.8 & 1766.1 & 1752.4 \\
\hline \multirow{3}{*}{$1^{\text {st }}$ July } & 1 & 59.0 & 65.0 & 62.0 & 1523.4 & 1661.5 & 1592.5 \\
\hline & 2 & 60.0 & 66.0 & 63.0 & 1549.7 & 1711.2 & 1630.5 \\
\hline & 3 & 61.0 & 67.0 & 64.0 & 1577.0 & 1739.1 & 1658.1 \\
\hline \multicolumn{2}{|c|}{ mean } & 60.0 & 66.0 & 63.0 & 1550.0 & 1703.9 & 1627.0 \\
\hline \multirow[t]{3}{*}{ mean HD } & 1 DAS & 64.3 & 66.3 & 65.3 & 1096.5 & 1133.5 & 1115.0 \\
\hline & $2 \mathrm{DAS}$ & 65.3 & 67.3 & 66.3 & 1694.0 & 1747.7 & 1720.9 \\
\hline & $3 \mathrm{DAS}$ & 66.3 & 68.3 & 67.3 & 1133.0 & 1177.4 & 1155.2 \\
\hline & & 65.3 & 67.3 & 66.3 & 1694.2 & 1745.4 & 1719.8 \\
\hline
\end{tabular}

Fayoum J. Agric. Res. \& Dev., Vol. 30, No.1, January, 2016 
Shehata, S.A. et al.,

Vegetative growth:

Data in Table (2 ) showed that there was a significant difference between the two hybrids on vegetative growth of corn plant. For instance, 353 hybrid had significantly increment in plant height, plant weight, plant diameter and number of leaves per plant compared with 323 hybrid. These results were agree with Attia (2006 )and Extassanawan et al., (2001). These results could be due to genetically condition of the two hybrids under this study (Attia, 2006).

Concerning the effect of planting date. Data revealed that the growth of maize measured in terms of plant height, plant weight, plant diameter and number of leaves / plant of baby corn plant varied significantly under different dates of sowing (Table). $1{ }^{\text {st }}$ May followed by $1{ }^{\text {st }}$ June increased significantly their characters than those of planted in $1^{\text {st }}$ july.

The interaction between hybrids and planting dates on vegetative growth were significant, however, 353 hybrid planted on $1^{\text {st }}$ may and $1^{\text {st }}$ June had the highest vegetative growth, while 323 hybrid planted in $1^{\text {st }}$ July gave the lowest ones in these characters . These results were agree with Darby and Luer (2002).

Table (2): Effect of hybrid and planting date on vegetative growth parameters of baby corn crop

\begin{tabular}{|c|c|c|c|c|c|c|}
\hline $\begin{array}{l}\text { hybrid } \\
\text { (H) }\end{array}$ & \multicolumn{2}{|c|}{$\begin{array}{l}\text { planting date } \\
\text { (SD) }\end{array}$} & $\begin{array}{l}\text { plant hight } \\
(\mathrm{cm})\end{array}$ & $\begin{array}{c}\text { No of leaves } \\
\text { /plant }\end{array}$ & $\begin{array}{c}\text { plant weight } \\
\text { (gm) }\end{array}$ & $\begin{array}{l}\text { Stem diamer } \\
(\mathrm{cm})\end{array}$ \\
\hline \multirow{3}{*}{323} & \multicolumn{2}{|c|}{$1^{\text {st }}$ May } & 2.30 & 15.44 & 481.35 & 2.32 \\
\hline & \multicolumn{2}{|c|}{$1^{\text {st }}$ June } & 2.00 & 14.01 & 474.08 & 2.10 \\
\hline & \multicolumn{2}{|c|}{$1^{\text {st }}$ july } & 1.81 & 12.81 & 455.19 & 1.83 \\
\hline \multicolumn{3}{|c|}{ mean } & 2.04 & 14.09 & 470.21 & 2.08 \\
\hline \multirow{3}{*}{353} & \multicolumn{2}{|c|}{$1^{\text {st }}$ May } & 2.68 & 16.78 & 559.75 & 2.73 \\
\hline & \multicolumn{2}{|c|}{$1^{\text {st }}$ June } & 2.34 & 14.74 & 520.70 & 2.34 \\
\hline & \multicolumn{2}{|c|}{$1^{\text {st }}$ july } & 2.10 & 13.20 & 480.31 & 2.08 \\
\hline \multicolumn{3}{|c|}{ mean } & 2.37 & 14.91 & 520.25 & 2.38 \\
\hline \multirow{3}{*}{ mean } & PD1 & & 2.49 & 16.11 & 520.55 & 2.53 \\
\hline & PD2 & & 2.17 & 14.38 & 497.39 & 2.22 \\
\hline & PD3 & & 1.96 & 13.01 & 467.75 & 1.96 \\
\hline \multicolumn{2}{|c|}{ mean } & & 2.21 & 14.50 & 495.23 & 2.23 \\
\hline \multicolumn{2}{|c|}{ LSD at 0.05 level } & $\mathrm{H}$ & 0.22 & 0.22 & 3.20 & 0.20 \\
\hline & & PD & 0.23 & 0.25 & 4.23 & 0.21 \\
\hline & & $\mathrm{H} * \mathrm{PD}$ & 0.26 & 0.29 & 6.25 & 0.22 \\
\hline
\end{tabular}

Yield and its components:

Data in Table (3) clearly indicated that 353 hybrid produced higher in ear weight, number of baby corn cobs $/ \mathrm{m}^{2}$, unhusked and husked total yield per Fadden, and than those obtained by 323 hybrid. The increase in total

Fayoum J. Agric. Res. \& Dev., Vol. 30, No.1, January, 2016 
EFFECT OF HYBRID, PLANTING DATES AND HARVESTING.... 99

yield for 353 hybrid may be due to increase in number of cobs / plant and ear weight. These results were agree with Attia (2006).

Table(3): effect of hybrid and planting date on yield and its components of baby corn crop

\begin{tabular}{|c|c|c|c|c|c|c|c|c|}
\hline $\begin{array}{c}\text { hybrid } \\
\text { (H) }\end{array}$ & $\begin{array}{c}\text { planting } \\
\text { date }(P D)\end{array}$ & $\begin{array}{c}\text { husked } \\
\text { ear } \\
\text { weight } \\
\text { (gm) }\end{array}$ & $\begin{array}{l}\text { unhusked } \\
\text { ear weight } \\
\text { (gm) }\end{array}$ & $\begin{array}{c}\text { No.of } \\
\text { cobs } / \mathbf{m} 2\end{array}$ & $\begin{array}{c}\text { husked } \\
\text { total } \\
\text { yeild gm } \\
/ \mathrm{m} 2\end{array}$ & $\begin{array}{c}\text { unhusked } \\
\text { total yeild } \\
\mathrm{gm} / \mathrm{m} 2\end{array}$ & $\begin{array}{c}\text { husked } \\
\text { total } \\
\text { yeild } \\
\text { T/Fed }\end{array}$ & $\begin{array}{c}\text { unhusked } \\
\text { total yeild } \\
\text { T/Fed }\end{array}$ \\
\hline \multirow{3}{*}{323} & $1^{\text {st }}$ May & 24.36 & 68.21 & 45.60 & 1110.82 & 3110.38 & 4.44 & 12.44 \\
\hline & $1^{\text {st }}$ June & 24.00 & 65.40 & 43.20 & 1036.80 & 2825.28 & 4.15 & 11.30 \\
\hline & $1^{\text {st }}$ July & 23.62 & 60.31 & 41.70 & 984.95 & 2514.93 & 3.94 & 10.06 \\
\hline \multicolumn{2}{|c|}{ mean } & 23.99 & 64.64 & 43.50 & 1044.19 & 2816.86 & 4.18 & 11.27 \\
\hline \multirow{3}{*}{353} & $1^{\text {st }}$ May & 25.80 & 73.82 & 47.30 & 1220.34 & 3491.69 & 4.88 & 13.97 \\
\hline & $1^{\text {st } J u n e}$ & 25.11 & 68.24 & 45.60 & 1145.02 & 3111.74 & 4.58 & 12.45 \\
\hline & $1^{\text {st }}$ July & 24.50 & 66.10 & 43.70 & 1070.65 & 2888.57 & 4.28 & 11.55 \\
\hline \multicolumn{2}{|c|}{ mean } & 25.14 & 69.39 & 45.53 & 1145.34 & 3159.41 & 4.58 & 12.64 \\
\hline \multirow{3}{*}{ mean } & PD1 & 25.08 & 71.02 & 46.45 & 1165.58 & 3298.65 & 4.66 & 13.20 \\
\hline & PD2 & 24.56 & 66.82 & 44.40 & 1090.91 & 2968.51 & 4.36 & 11.87 \\
\hline & PD3 & 24.06 & 63.21 & 42.70 & 1027.80 & 2698.85 & 4.11 & 10.81 \\
\hline \multicolumn{2}{|c|}{ mean } & 24.57 & 67.01 & 44.52 & 1094.76 & 2988.13 & 4.38 & 11.95 \\
\hline \multicolumn{9}{|c|}{ LSD at 0.05 level } \\
\hline & $\mathrm{H}$ & 0.23 & 1.03 & 1.23 & 26.83 & 34.11 & 0.21 & 0.34 \\
\hline & PD & 0.26 & 1.24 & 1.35 & 28.11 & 36.23 & 0.24 & 0.60 \\
\hline & $\mathrm{H} * \mathrm{PD}$ & 0.26 & 1.39 & 1.40 & 29.43 & 40.11 & 0.24 & 0.40 \\
\hline
\end{tabular}

Concerning the effect of planting date, data revealed that the total yield and its components of baby corn plants measured in terms of total yield of unhusked and husked ears and number of cobs $/ \mathrm{m}^{2}$ varied significantly under different dates of sowing. Significant decrease in baby corn ear weight, number of ears $/ \mathrm{m}^{2}$, husked and unhusked total yield $/ \mathrm{m}^{2}$ with advanced date of sowing, however, the highest total yield and its components were obtained from earlier dates of sowing ( $1{ }^{\text {st }}$ May), while the lowest ones were obtained from the late sowing date. These results were agree with Singh and Gupta. (2002). who found that, the variation in the yield of maize at different dates are attributed to the efficient use of moisture by the crop with earlier dates of sowing where the moisture remained conserved within the soil profile during the earlier dates that resulted in producing more number of cobs as compared to late sowing date. However, no significant differences between planting dateson baby corn ear weight.

Regarding the interactions between hybrid and planting dates, data in Table (3) showed that the maximum values of total yield in unhusked and husked of total yield and number of cobs/ plant and ear weight were recorded by planting on $1^{\text {st }}$ may with 353 hybrid. This could be due to the relationship between the vegetative growth and yield parameters. Similar opinions were reported by Darby and Luer (2002).

Fayoum J. Agric. Res. \& Dev., Vol. 30, No.1, January, 2016 
Shehata, S.A. et al.,

Ear quality :

Ear length and ear diameter

Data in Table (4) indicated that significant differences among various corn hybrids, however,353 hybrid had significantly the lowest and highest values of ear length and ear diameter respectively as compared with 323 hybrid. These results agree with El- Bassiouny et al., (2003) and Attia (2006

Data in Table (4) revealed that planting date had significant effect on ear length and diameter of baby corn, the highest and lowest ear length were obtained on 1 st May and 1 st july planting date which were about 10.76 and $8.76 \mathrm{~cm}$, respectively . regarding the ear diameter the highest and lowest value was obtained on $1{ }^{\text {st }}$ July and on $1{ }^{\text {st }}$ May planting dates being about 11.97 and $10.02 \mathrm{~mm}$ respectively. These results were agree with Oktem (2004).

For the effect of harvesting date , data showed that ear length and diameter increased significantly with the delay of harvest date. Results are agreement with the Galinat and Lin (1988) and El- Bassiouny et al., (2003).

Regarding the interaction between hybrids and planting dates, data in Table (2) show that the highest and lowest ear length were obtained from 1 st May planting date with 323 hybrid and $1{ }^{\text {st }}$ July planting date with 353 hybrid, which were about $11.91 \mathrm{~cm}$ and $7.94 \mathrm{~cm}$. respectively. Regarding the ear diameter the highest and lowest value was obtained on $1^{\text {st }}$ July with hybrid 353 and 1 st May with 323 hybrid which were about 12.89 and $9.46 \mathrm{~mm}$ respectively. These results were agree with El- Bassiouny et al., (2003).

The interaction between hybrids and harvesting dates were significant effects. However the highest and lowest ear length was obtained from 323hybrid harvested after 3 days of silk emergence and 353 hybrid harvested after 1 day of silk emergence, which were about 11.86 and $8.11 \mathrm{~cm}$ respectively while the highest and lowest ear diameter was obtained from 353 hybrid after 3 days from silk emergence and 323 hybrid harvested after one day after silking which were $12.32 \mathrm{~mm}$ and $9.61 \mathrm{~mm}$ respectively. These results were agree with El- Bassiouny et al., (2003).

Data in Table (4) indicated that significant interaction between the planting date and harvesting date of ear length, data showed that the highest and lowest ear length were obtained from $1{ }^{\text {st }}$ May planting date and harvest after 3 days from silk emergence and 1 july planting date and harvested after 1 day from silk emergence respectively while the highest and lowest ear diameter was obtained from $1{ }^{\text {st }}$ July planting date which harvested after 3 days from silking and $1{ }^{\text {st }}$ May planting date which harvested after 1 day after silking.

Concerning the effect of the interaction between hybrids, planting date and harvesting date in Table (4) data showed that the highest and lowest ear length were obtained from 323 hybrid, sowing at $1{ }^{\text {st }}$ May and harvested after 3 days from silk emergence and 353 hybrid, 1 st July sowing date and

Fayoum J. Agric. Res. \& Dev., Vol. 30, No.1, January, 2016 
EFFECT OF HYBRID, PLANTING DATES AND HARVESTING.... 101 harvested after 1 day from silking. However ,concerning ear diameter, the highest and lowest value were obtained from 353 hybrid $1{ }^{\text {st }}$ July planting date and harvested after 3 days of silk emergence and 323 hybrid $1{ }^{\text {st }}$ May planting date harvested after 1 day after silk emergence.

Table (4): Effect of hybrid, sowind date and harvest date on ear length and ear diameter of baby corn crop.

\begin{tabular}{|c|c|c|c|c|c|c|c|}
\hline \multirow{2}{*}{$\begin{array}{l}\text { planting } \\
\text { date } \\
\text { (PD) }\end{array}$} & \multirow[b]{2}{*}{$\begin{array}{l}\text { harvest } \\
\text { date (HD) }\end{array}$} & \multicolumn{2}{|c|}{$\begin{array}{l}\text { ear length }(\mathrm{cm}) \\
\text { hybrid }(\mathbf{H})\end{array}$} & \multirow[b]{2}{*}{ mean } & \multicolumn{2}{|c|}{$\begin{array}{c}\text { ear diameter }(\mathrm{mm}) \\
\operatorname{hybrid}(\mathbf{H})\end{array}$} & \multirow[b]{2}{*}{ mean } \\
\hline & & 323 & 353 & & 323 & 353 & \\
\hline \multirow{4}{*}{$1{ }^{\text {st }}$ May } & $1 \mathrm{DAS}$ & 10.80 & 9.12 & 9.96 & 9.07 & 10.14 & 9.61 \\
\hline & 2 DAS & 11.42 & 9.32 & 10.37 & 9.52 & 10.38 & 9.95 \\
\hline & 3 DAS & 13.51 & 10.41 & 11.96 & 9.78 & 11.23 & 10.51 \\
\hline & mean & 11.91 & 9.62 & 10.76 & 9.46 & 10.58 & 10.02 \\
\hline \multirow{4}{*}{$1^{\text {st }}$ June } & $1 \mathrm{DAS}$ & 9.50 & 8.02 & 8.76 & 9.42 & 10.42 & 9.92 \\
\hline & 2 DAS & 10.37 & 8.79 & 9.58 & 9.73 & 10.97 & 10.35 \\
\hline & 3 DAS & 11.83 & 10.32 & 11.08 & 10.31 & 11.78 & 11.05 \\
\hline & mean & 10.57 & 9.04 & 9.81 & 9.82 & 11.06 & 10.44 \\
\hline \multirow{4}{*}{$1^{\text {st }}$ July } & $1 \mathrm{DAS}$ & 9.02 & 7.20 & 8.11 & 10.35 & 11.89 & 11.12 \\
\hline & 2 DAS & 9.45 & 7.98 & 8.72 & 10.94 & 12.84 & 11.89 \\
\hline & $3 \mathrm{DAS}$ & 10.24 & 8.64 & 9.44 & 11.87 & 13.95 & 12.91 \\
\hline & mean & 9.57 & 7.94 & 8.76 & 11.05 & 12.89 & 11.97 \\
\hline \multirow{4}{*}{ mean } & $1 \mathrm{DAS}$ & 9.77 & 8.11 & 8.94 & 9.61 & 10.82 & 10.22 \\
\hline & $2 \mathrm{DAS}$ & 10.41 & 8.70 & 9.56 & 10.06 & 11.40 & 10.73 \\
\hline & 3 DAS & 11.86 & 9.79 & 10.83 & 10.65 & 12.32 & 11.49 \\
\hline & mean & 10.68 & 8.87 & & 10.11 & 11.51 & \\
\hline \multicolumn{8}{|l|}{$\begin{array}{c}\text { LSD at } \\
0.05 \text { level }\end{array}$} \\
\hline & PD & 0.28 & & & PD & 0.31 & \\
\hline & HD & 0.29 & & & HD & 0.32 & \\
\hline & $\mathrm{H}$ & 0.33 & & & $\mathrm{H}$ & 0.34 & \\
\hline & $\mathrm{H}^{*} \mathrm{PD}$ & 0.42 & & & $\mathrm{H}^{*} \mathrm{PD}$ & 0.32 & \\
\hline & $\mathrm{H}+\mathrm{HD}$ & 0.42 & & & $\mathrm{H}+\mathrm{HD}$ & 0.40 & \\
\hline & PD*HD & 0.32 & & & PD*HD & 0.38 & \\
\hline & $\mathrm{H}+\mathrm{PD}+\mathrm{HD}$ & 0.30 & & & $\mathrm{H}+\mathrm{PD}+\mathrm{HD}$ & 0.31 & \\
\hline
\end{tabular}

Ear length and ear diameter are important characters being considered in selecting the high products in convert industry factories. Despite the fact that the ear diameter increased on 1 st July planting date, its popularity in markets decreased because of the increase in ear diameter and poor quality. therefore, the best value of ear length and ear diameter concerning to marketability were obtained from 353 hybrid obtained from $1^{\text {st }}$ may planting date and harvesting after 2 days for silk emergence being about $9.32 \mathrm{~cm}$ and $10.38 \mathrm{~mm}$ respectively.

These results were agree with Darby and Luer (2002). Found that the best value of ear length and diameter to marketability were 7-9 centimeters

Fayoum J. Agric. Res. \& Dev., Vol. 30, No.1, January, 2016 
long and $1.2-1.5$ centimeters wide as a medium size, and $4-7$ centimeters long with 1.0-1.2 cm diameter for small size or $9-13 \mathrm{~cm}$ long and $1.5 \mathrm{~cm}$ wide for large size as which also size requirements vary according to the market.

\section{Storability :}

\section{General appearance (GA):}

Data in Table (5) indicated that general appearance of baby corn ears were deteriorated during storage period. The decrease of (GA) during storage period might be due morphological defects such as dryness change in color, browning or decay (Rodove et al.,2000)

Concerning the effect of planting date, data revealed that planting date had a significant effect on general appearance of baby corn ears during storage. However, baby corn ears obtained from planting date $1^{\text {st }}$ May gave the highest values of GA, while the lowest ones obtained from planting date $1^{\text {st }} \mathrm{July}$.

Table (5) : effect of planting date, harvest date and storage period on general appearance score of baby corn ears during cold storage

\begin{tabular}{|c|c|c|c|c|c|c|}
\hline \multirow{2}{*}{$\begin{array}{c}\text { planting } \\
\text { date (PD) }\end{array}$} & \multirow{2}{*}{$\begin{array}{c}\text { harvest } \\
\text { date (HD) }\end{array}$} & \multicolumn{4}{|c|}{ storage period (days) (SP) } & \multirow{2}{*}{ mean } \\
\hline & & start & 5 & 10 & 15 & \\
\hline \multirow{3}{*}{$1^{\text {st }}$ May } & 1 DAS & 9.00 & 9.00 & 7.00 & 5.33 & 7.58 \\
\hline & $2 \mathrm{DAS}$ & 9.00 & 9.00 & 9.00 & 8.33 & 8.83 \\
\hline & $3 \mathrm{DAS}$ & 9.00 & 9.00 & 7.00 & 3.67 & 7.17 \\
\hline \multicolumn{2}{|c|}{ mean } & 9.00 & 9.00 & 7.67 & 5.78 & 7.86 \\
\hline \multirow{3}{*}{$1^{\text {st }}$ June } & 1 DAS & 9.00 & 8.33 & 6.67 & 5.33 & 7.33 \\
\hline & $2 \mathrm{DAS}$ & 9.00 & 9.00 & 7.00 & 5.67 & 7.67 \\
\hline & 3 DAS & 9.00 & 9.00 & 5.00 & 1.67 & 6.17 \\
\hline \multicolumn{2}{|c|}{ mean } & 9.00 & 8.78 & 6.22 & 4.22 & 7.06 \\
\hline \multirow{3}{*}{$\mathbf{1}^{\text {st }}$ July } & $1 \mathrm{DAS}$ & 9.00 & 7.67 & 5.00 & 2.33 & 6.00 \\
\hline & 2 DAS & 9.00 & 8.33 & 6.67 & 4.33 & 7.08 \\
\hline & $3 \mathrm{DAS}$ & 9.00 & 7.00 & 4.33 & 1.00 & 5.33 \\
\hline \multicolumn{2}{|c|}{ mean } & 9.00 & 7.67 & 5.33 & 2.55 & 6.14 \\
\hline & $1 \mathrm{DAS}$ & 9.00 & 8.33 & 6.22 & 4.33 & 6.97 \\
\hline & 2 DAS & 9.00 & 8.78 & 7.56 & 6.11 & 7.86 \\
\hline & 3 DAS & 9.00 & 8.33 & 5.44 & 2.11 & 6.22 \\
\hline \multicolumn{2}{|c|}{ mean } & 9.00 & 8.48 & 6.41 & 4.18 & \\
\hline \multicolumn{2}{|c|}{ LSD at 0.05 level } & PD & 0.22 & & & \\
\hline & & $\mathrm{HD}$ & 0.26 & & & \\
\hline & & S P & 0.29 & & & \\
\hline & & $\mathrm{PD} * \mathrm{HD}$ & 3.00 & & & \\
\hline & & $\mathrm{PD} * \mathrm{SP}$ & 0.31 & & & \\
\hline & & HD*SP & 0.33 & & & \\
\hline & & PD*HD*SP & 0.38 & & & \\
\hline
\end{tabular}

Regarding the effect of harvesting date, data showed that GA of ears was significantly affected by different harvesting date, however, the highest values of GA resulted from ears obtained from the second harvesting date, while the lowest ones were obtained from the third harvesting date. These results were agree with EL-Bassiouny et al.,(2003).

Fayoum J. Agric. Res. \& Dev., Vol. 30, No.1, January, 2016 


\section{EFFECT OF HYBRID, PLANTING DATES AND HARVESTING.... 103}

Concerning the interaction between planting date and harvesting date on GA of baby corn ears during storage, data presented in Table (5) showed that the highest values of GA of baby corn ears recorded by planting on $1{ }^{\text {st }}$ May and harvesting after second day from silk emergence which gave excellent appearance as compared with the other planting dates and harvesting dates.

Regarding the effect of planting date, harvesting date and storage period on GA of baby corn ears ,data in Table(5) showed that, GA in ears obtained from planted on $1^{\text {st }}$ May and harvested after 2 days from silk emergence did not exhibit any changes in their appearance till the end of storage period (15 days). However, ears obtained from planting on $1{ }^{\text {st }}$ July and harvested after 3 days from silk emerge showed poor appearance after the same period.

\section{Weight loss}

Data in table (6) showed that the period of storage had a significant effect of the percentage of weight loss, the loss in weight was increased as the storage period elapsed in two seasons. The decrease in fresh weight of baby corn ears might be attributed to the loss in moisture through transpiration and loss in dry matter content through respiration (Wills et al., 1981). These results agree with those obtained by Attia et al.,(2011).

Table (6) : effect of planting date, harvest date and storage period on weight loss \% of baby corn ears during cold storage

\begin{tabular}{|c|c|c|c|c|c|c|}
\hline \multirow{2}{*}{$\begin{array}{l}\text { planting } \\
\text { date (PD) }\end{array}$} & \multirow{2}{*}{$\begin{array}{c}\text { harvest } \\
\text { date (HD) }\end{array}$} & \multicolumn{4}{|c|}{ storage period (days) (SP) } & \multirow{2}{*}{ mean } \\
\hline & & start & 5 & 10 & 15 & \\
\hline \multirow{3}{*}{$1^{\text {st }}$ May } & 1 DAS & 0.00 & 0.49 & 0.79 & 5.49 & 1.69 \\
\hline & $2 \mathrm{DAS}$ & 0.00 & 0.38 & 0.63 & 1.65 & 0.67 \\
\hline & $3 \mathrm{DAS}$ & 0.00 & 0.36 & 0.55 & 1.16 & 0.52 \\
\hline \multicolumn{2}{|c|}{ mean } & 0.00 & 0.41 & 0.66 & 2.77 & 0.96 \\
\hline \multirow{3}{*}{$1{ }^{\text {st }}$ June } & 1 DAS & 0.00 & 1.52 & 2.54 & 3.28 & 1.84 \\
\hline & 2 DAS & 0.00 & 0.59 & 1.19 & 1.64 & 0.86 \\
\hline & $3 \mathrm{DAS}$ & 0.00 & 0.52 & 1.05 & 1.40 & 0.74 \\
\hline \multicolumn{2}{|c|}{ mean } & 0.00 & 0.88 & 1.59 & 2.11 & 1.14 \\
\hline \multirow{3}{*}{$1^{\text {st }}$ July } & $1 \mathrm{DAS}$ & 0.00 & 2.50 & 4.30 & 5.90 & 2.88 \\
\hline & 2 DAS & 0.00 & 2.00 & 3.80 & 5.70 & 2.41 \\
\hline & $3 \mathrm{DAS}$ & 0.00 & 1.25 & 3.70 & 4.70 & 3.18 \\
\hline \multicolumn{2}{|c|}{ mean } & 0.00 & 1.92 & 3.93 & 5.43 & 3.94 \\
\hline & 1 DAS & 0.00 & 1.50 & 2.54 & 4.89 & 2.23 \\
\hline & 2 DAS & 0.00 & 0.99 & 1.87 & 3.00 & 1.47 \\
\hline & $3 \mathrm{DAS}$ & 0.00 & 0.71 & 1.77 & 2.42 & 1.22 \\
\hline \multicolumn{2}{|c|}{ mean } & 0.00 & 1.07 & 2.06 & 3.44 & \\
\hline \multicolumn{2}{|c|}{ LSD at 0.05 level } & PD & 0.21 & & & \\
\hline & & HD & 0.27 & & & \\
\hline & & S P & 0.30 & & & \\
\hline & & $\mathrm{PD} * \mathrm{HD}$ & 0.26 & & & \\
\hline & & PD*SP & 0.32 & & & \\
\hline & & HD*SP & 0.31 & & & \\
\hline & & PD*HD*SP & 0.33 & & & \\
\hline
\end{tabular}

Fayoum J. Agric. Res. \& Dev., Vol. 30, No.1, January, 2016 
Concerning the effect of planting date results indicated that planting date of baby corn ears had a significant effect on weight loss, however, the lowest value of weight loss were detected in baby corn planted in the $1{ }^{\text {st }}$ May while the highest values were recorded for the third planting date $1^{\text {st }} \mathrm{July}$, the baby corn planted at the second planting date was in between. These results were in agreement with, El-Bassiouny et al.,(2003)

Regarding harvesting date, data showed that harvesting date of baby corn had a significant effect on weight loss percentage during storage, however, weight loss percentage decreased significantly with the delay of harvest date, thus weight loss percentage was higher in ears harvested after one day from silk emergence compared with those harvested at second and third day from silk emergence. Results are in line with those obtained by Attia,(2006). The decreased weight loss due to the ear aging might be attributed to the lower moisture content and higher dry matter compared to those younger ears (Attia,2006)

Regarding the interaction between planting date and harvesting date. Data shown in Table(6 )indicated that ears obtained from baby corn planted in third planting date and picked after one day from silk emergence had the highest percent in weight loss, whereas ears obtained from the first planting date and harvested after 2 and 3days from silking showed the lowest weight loss percentage with no significant differences between them.

Concerning the interaction between planting date, harvesting date and storage period. Data in the same Table (6) revealed that, after 15 days of storage, there were significant differences, however, baby corn ears obtained from the third planting date and the first harvest date had the highest percentage in weight loss, these results were in agreement with those obtained by Attia,2006.

Color $(\mathrm{L})$ value

Data in Table (7) showed that the L value of ears was significantly decreased with the progress of storage period in the two seasons indicating that the browning process of ears developed and reached darker with storage, similar results were found with Attia et al.,(2011).

Concerning planting date, results indicating that the highest $\mathrm{L}$ value was detected in baby corn ears obtained from planting at $1{ }^{\text {st }}$ May indicating lighter color, while the lowest $\mathrm{L}$ value was recorded in ears obtained from planting at $1{ }^{\text {st }}$ July, indicating that darker color. These results were agree with El- Bassiouny et al.,(2003).

Regarding the effect of harvesting date, data showed that $\mathrm{L}$ value of ears was significantly affected by different harvesting date. However, the highest value of $\mathrm{L}$ (70.08) resulted from ears obtained from the second harvesting date, indicating lighter color, while the lowest ones (65.84) were

Fayoum J. Agric. Res. \& Dev., Vol. 30, No.1, January, 2016 
EFFECT OF HYBRID, PLANTING DATES AND HARVESTING.... 105 obtained from the third harvesting date, indicating darker color. These results were agree with Attia., 2006).

A range of L, lightness (75.27) to darkness (60.15) of color was presented within the interaction between planting date and harvesting date (Table 7). The color of ears obtained from planting at $1{ }^{\text {st }}$ May and harvesting after 2 days from silk emergence is lighter $(\mathrm{L}=75.27)$ compared with ears obtained from planting at $1^{\text {st }}$ July and harvested after 3 day from silk emergence, color which is darker (mean $\mathrm{L}=60.15$ ).

Table (7): effect of planting date, harvest date and storage period on color $(\mathrm{L})$ values of baby corn ears during cold storage

\begin{tabular}{|c|c|c|c|c|c|c|}
\hline \multirow{2}{*}{$\begin{array}{c}\text { planting } \\
\text { date (PD) }\end{array}$} & \multirow{2}{*}{$\begin{array}{c}\text { harvest } \\
\text { date (HD) }\end{array}$} & \multicolumn{4}{|c|}{ storage period (days) (SP) } & \multirow{2}{*}{ mean } \\
\hline & & start & 5 & 10 & 15 & \\
\hline \multirow{3}{*}{$1^{\text {st }}$ May } & 1 DAS & 74.13 & 73.65 & 78.35 & 71.34 & 74.37 \\
\hline & $2 \mathrm{DAS}$ & 76.30 & 75.97 & 74.82 & 73.97 & 75.27 \\
\hline & 3 DAS & 74.76 & 74.59 & 73.16 & 71.89 & 73.60 \\
\hline \multicolumn{2}{|c|}{ mean } & 75.06 & 74.74 & 75.44 & 72.40 & 74.41 \\
\hline \multirow{3}{*}{1 st June } & 1 DAS & 67.62 & 65.23 & 63.42 & 61.53 & 64.45 \\
\hline & 2 DAS & 71.14 & 70.26 & 69.22 & 67.23 & 69.46 \\
\hline & 3 DAS & 65.22 & 64.34 & 62.17 & 60.24 & 62.99 \\
\hline \multicolumn{2}{|c|}{ mean } & 67.99 & 66.61 & 64.94 & 63.00 & 65.64 \\
\hline \multirow{3}{*}{$1^{\text {st }}$ July } & 1 DAS & 63.26 & 62.15 & 60.25 & 59.72 & 61.35 \\
\hline & 2 DAS & 67.33 & 66.36 & 65.11 & 63.28 & 65.52 \\
\hline & 3 DAS & 62.11 & 61.00 & 59.26 & 58.22 & 60.15 \\
\hline \multicolumn{2}{|c|}{ mean } & 64.23 & 63.17 & 61.54 & 60.41 & 62.34 \\
\hline & 1 DAS & 68.34 & 67.01 & 67.34 & 64.20 & 66.72 \\
\hline & $2 \mathrm{DAS}$ & 71.59 & 70.86 & 69.72 & 68.16 & 70.08 \\
\hline & $3 \mathrm{DAS}$ & 67.36 & 66.64 & 64.86 & 63.45 & 65.58 \\
\hline \multicolumn{2}{|c|}{ mean } & 69.10 & 68.17 & 67.31 & 65.27 & 67.46 \\
\hline \multicolumn{2}{|c|}{ LSD at 0.05 level } & PD & 0.19 & & & \\
\hline & & $\mathrm{HD}$ & 0.20 & & & \\
\hline & & S P & 0.21 & & & \\
\hline & & PD*HD & 0.22 & & & \\
\hline & & $\mathrm{PD} * \mathrm{SP}$ & 0.29 & & & \\
\hline & & HD*SP & 0.32 & & & \\
\hline & & PD*HD*SP & 0.36 & & & \\
\hline
\end{tabular}

Color (b value)

Data in Table (8) showed that the $b$ value of ears was significantly decreased with the progress of storage period in the two seasons, these results were agree with Attia et al.,(2011).

Concerning planting date, results indicated that the highest $b$ value were detected in baby corn ears obtained from planting on $1{ }^{\text {st }}$ May indicating highest yellowing of the ears. Indeed, the color of baby corn ears were maintained while the lowest $b$ value were observed in planting on $1^{\text {st }} \mathrm{July}$, indicating yellowing of ears. These results were true in the two seasons and agree with El-Bassiouny et al.,(2003).

Fayoum J. Agric. Res. \& Dev., Vol. 30, No.1, January, 2016 
Shehata, S.A. et al.,

Table (8): effect of planting date, harvest date and storage period on color (b) values of baby corn ears during cold storage

\begin{tabular}{|c|c|c|c|c|c|c|}
\hline \multirow{2}{*}{$\begin{array}{c}\text { planting } \\
\text { date (PD) }\end{array}$} & \multirow{2}{*}{$\begin{array}{c}\text { harvest } \\
\text { date (HD) }\end{array}$} & \multicolumn{4}{|c|}{ storage period (days) (SP) } & \multirow{2}{*}{ mean } \\
\hline & & start & 5 & 10 & 15 & \\
\hline \multirow{3}{*}{$\mathbf{1}^{\text {st }}$ May } & 1 DAS & 36.18 & 34.22 & 31.45 & 29.23 & 32.77 \\
\hline & 2 DAS & 36.38 & 37.14 & 33.56 & 31.21 & 34.57 \\
\hline & 3 DAS & 32.14 & 30.13 & 29.22 & 26.14 & 29.41 \\
\hline \multicolumn{2}{|c|}{ mean } & 34.90 & 33.83 & 31.41 & 28.86 & 32.25 \\
\hline \multirow{3}{*}{$\mathbf{1}^{\text {st }} \mathbf{J u n e}$} & 1 DAS & 31.26 & 30.57 & 29.24 & 27.42 & 29.62 \\
\hline & 2 DAS & 34.11 & 33.26 & 30.24 & 29.15 & 31.69 \\
\hline & $3 \mathrm{DAS}$ & 30.56 & 26.76 & 24.13 & 21.17 & 25.66 \\
\hline \multicolumn{2}{|c|}{ mean } & 31.98 & 30.20 & 27.87 & 25.91 & 28.99 \\
\hline \multirow{3}{*}{$1^{\text {st }}$ July } & $1 \mathrm{DAS}$ & 31.24 & 29.14 & 25.52 & 23.41 & 27.33 \\
\hline & $2 \mathrm{DAS}$ & 33.11 & 31.26 & 30.24 & 28.67 & 30.82 \\
\hline & 3 DAS & 27.22 & 25.14 & 23.67 & 22.13 & 24.54 \\
\hline \multicolumn{2}{|c|}{ mean } & 30.52 & 28.51 & 26.48 & 24.74 & 27.56 \\
\hline & 1 DAS & 32.89 & 31.31 & 28.74 & 26.69 & 29.91 \\
\hline & $2 \mathrm{DAS}$ & 34.53 & 33.89 & 31.35 & 29.68 & 32.36 \\
\hline & 3 DAS & 29.97 & 27.34 & 25.67 & 23.15 & 26.53 \\
\hline \multicolumn{2}{|c|}{ mean } & 32.47 & 30.85 & 28.59 & 26.50 & 29.60 \\
\hline \multicolumn{2}{|c|}{ LSD at 0.05 level } & PD & 0.61 & & & \\
\hline & & HD & 0.66 & & & \\
\hline & & S P & 0.70 & & & \\
\hline & & $\mathrm{PD} * \mathrm{HD}$ & 0.74 & & & \\
\hline & & PD*SP & 0.79 & & & \\
\hline & & HD*SP & 0.82 & & & \\
\hline & & PD*HD*SP & 0.84 & & & \\
\hline
\end{tabular}

Regarding the effect of harvesting date, data showed that $b$ value of ears was significantly affected by different harvesting dates, however, the highest value of $b$ value resulted from ears obtained from the second harvesting date, indicating light yellowing color while the lowest ones were obtained from third harvesting date, indicated yellowing color. These results agree with Attia,(2006).

Results presented in Table (8) also reported that the interactions between planting date and harvesting date were significant effects. Therefore baby corn ears obtained from planting at $1^{\text {st }}$ May and harvested after 2 days from silk emergence gave the highest $b$ value indicating light yellowing of the ears. These results agree with El- Bassiouny et al.,(2003).

Concerning the interaction between planting date, harvesting date and storage period, data in the same table revealed that there were significant differences after 3 weeks of storage, however, baby corn ears obtained from the first planting date and harvested after 2 days from silking had the highest $b$ value indicating that light yellowing of the ears during all storage period. Indeed, the color baby corn ears was maintained, however, baby corn ears obtained from third planting date and harvested after 3 days from silk emergence had the lowest

Fayoum J. Agric. Res. \& Dev., Vol. 30, No.1, January, 2016 
EFFECT OF HYBRID, PLANTING DATES AND HARVESTING.... 107

$\mathrm{b}$ value indicating yellow color of ears during all storage period. These results were in agreement with these obtained by El- Bassiouny (2003).

\section{Total sugars:}

Data in Table (9) showed that total sugars content of baby corn ears decreased as the storage period was extended. These results agree with those obtained by Attia (2006) and Attia et al., (2011) and might be due to the consumption of sugars through respiration.

Concerning the effect of planting date, data revealed that planting date had significantly effect on total sugars content of baby corn ears during storage. however, baby corn ears obtained from planting date $1^{\text {st }}$ May gave the highest values of total sugars, while the lowest ones obtained from planting date $1^{\text {st }}$ July . These results were in agreement with those obtained by El- Bassiouny et al., (2003).

Regarding the effect of harvesting date, data showed that total sugars content of ears was significantly affected by different harvesting date during storage. However, ears obtained from the second harvesting date gave the higher values of total sugars content while the lowest ones were obtained from the third harvesting date. These results were in agreement with Attia (2006).

Table (9) : effect of planting date, harvest date and storage period on total sugrs content $(\mathrm{mg} / 100 \mathrm{~g} \mathrm{~F} \mathrm{~W})$ of baby corn ears during cold storage

\begin{tabular}{|c|c|c|c|c|c|c|}
\hline \multirow{2}{*}{$\begin{array}{c}\text { planting } \\
\text { date (PD) }\end{array}$} & \multirow{2}{*}{$\begin{array}{c}\text { harvest } \\
\text { date (HD) }\end{array}$} & \multicolumn{4}{|c|}{ storage period (days) (SP) } & \multirow[b]{2}{*}{ mean } \\
\hline & & start & 5 & 10 & 15 & \\
\hline \multirow{3}{*}{$1^{\text {st }}$ May } & 1 DAS & 11.20 & 11.00 & 10.60 & 10.00 & 10.70 \\
\hline & 2 DAS & 12.60 & 12.40 & 12.10 & 11.80 & 12.23 \\
\hline & 3 DAS & 10.80 & 10.50 & 10.20 & 9.80 & 10.33 \\
\hline \multicolumn{2}{|c|}{ mean } & 11.53 & 11.30 & 10.97 & 10.53 & 11.08 \\
\hline \multirow{3}{*}{$1^{\text {st }}$ June } & $1 \mathrm{DAS}$ & 11.00 & 10.60 & 10.10 & 9.80 & 10.38 \\
\hline & 2 DAS & 12.20 & 12.00 & 11.80 & 11.50 & 11.88 \\
\hline & 3 DAS & 10.60 & 10.10 & 9.80 & 9.60 & 10.03 \\
\hline \multicolumn{2}{|c|}{ mean } & 11.27 & 10.90 & 10.57 & 10.30 & 10.76 \\
\hline \multirow{3}{*}{$1^{\text {st }}$ July } & $1 \mathrm{DAS}$ & 11.80 & 10.30 & 9.70 & 9.40 & 10.30 \\
\hline & 2 DAS & 11.90 & 11.60 & 11.20 & 10.90 & 11.40 \\
\hline & 3 DAS & 10.00 & 9.80 & 9.30 & 8.80 & 9.48 \\
\hline \multicolumn{2}{|c|}{ mean } & 11.23 & 10.57 & 10.07 & 9.70 & 10.39 \\
\hline & 1 DAS & 11.33 & 10.63 & 10.13 & 9.73 & 10.46 \\
\hline & 2 DAS & 12.23 & 12.00 & 11.70 & 11.40 & 11.83 \\
\hline & 3 DAS & 10.47 & 10.13 & 9.77 & 9.40 & 9.94 \\
\hline \multicolumn{2}{|c|}{ mean } & 11.34 & 10.92 & 10.53 & 10.18 & \\
\hline \multicolumn{2}{|c|}{ LSD at 0.05 level } & PD & 0.18 & & & \\
\hline & & $\mathrm{HD}$ & 0.20 & & & \\
\hline & & S P & 0.22 & & & \\
\hline & & $\mathrm{PD} * \mathrm{HD}$ & 0.24 & & & \\
\hline & & $\mathrm{PD} * \mathrm{SP}$ & 0.24 & & & \\
\hline & & HD*SP & 0.25 & & & \\
\hline & & PD*HD*SP & 0.27 & & & \\
\hline
\end{tabular}

Fayoum J. Agric. Res. \& Dev., Vol. 30, No.1, January, 2016 
Shehata, S.A. et al.,

The interaction between planting date and harvesting date was significant for total sugars content resulted by planting on $1^{\text {st }}$ May and harvesting after 2 days from silk emergence as compared with the other planting date and harvesting date. These results were agree with ElBassiouny et al., (2003).

Regarding the effect of planting date, harvesting date and storage period on total sugars content, data showed that after 15 days of storage the highest value of total sugars content were obtained from the first planting date $(1$ st May) and harvested after 2 days from silk emergence while, the lowest one were found from the third planting date and harvested after 3 days from silk emergence.

\section{CONCLUSION}

From the previous results it was concluded that, results revealed that 353 hybrid had significantly increment in vegetative growth parameters and produced higher total yield and its components per Fadden than those obtained by 323 hybrid, the best value of ear length and ear diameter concerning to marketability were obtained from 353 hybrid which planted in $1{ }^{\text {st }}$ May and harvested after 2 days from silk emergence being about $9.32 \mathrm{~cm}$ and 10.38 $\mathrm{mm}$, respectively and maintained quality of ears during cold storage.

REFERENCES

Adams, R. M., C. Rosenzweig, R. Peart, J. Ritchie, B. McCarl, J. Glyer, B. Curry, J. Jones, K. Boote, and L. Allen. (1990). "Global Climate Change and U.S. Agriculture." Nature 345: 219-224.

Aekatasanawan, C. (2001). Baby corn. Hallauer, A.R. Specialty Corns. 2 ed. Madison, CRC Press LLC, 2001, v.2, cap.9, p.275-293.

Attia , M.M. (2006).Effect of some pre and postharvest treatments on quality of sweet corn. Ph.D thesis. Faculty of Agriculture (Horticulture), Ain Shams University.

Attia M.M., S.M.M.Saleh and E.M. El-Shabrawy.(2011). Effect of antibrowning agents and wrapping films on browning inhibition and maintaining quality of baby corn during storage. J.Plant Production, Mansoura Univ., 2(12): 16677 - 1682, 2011.

Bindi M, L. Fibbi, B. Gozzini, S .Orlandini and F .Miglietta (1996). Modeling the impact of future climate scenarios on yield and yield variability of grapevine. Clim Res 7:213-224

Darby, H. and J.Luer (2002). Evaluation of narrow- row corn forage yield and quality. Agronomy.J. 94:321- 325.

El-Bassiouny, R.I.,S.K. El-Seifi and G.F.Omar.(2003). Studies on yield and storability of baby corn ears.J. Agric. Sci. Mansoura Univ., 28(3):2099-2115.

Galinat, W.C and B.Y.Lin.(1988). Baby corn production in taiwan and future outlook for production in the United States. Econ. Bot,42: 132- 134.

Fayoum J. Agric. Res. \& Dev., Vol. 30, No.1, January, 2016 
EFFECT OF HYBRID, PLANTING DATES AND HARVESTING.... 109

Kheibari, M.N.K., S.K.Khorasani and G.Taheri.(2014). Effect of plant density and variety on some of morphological traits, yield and yield components of baby corn (zeam mays L.). Inter.Res.J.of App. \& Basic sci.3(10): 2009- 2014.

Kumar.S.and F.Kallo.(2000). Attributes of maize genotype for baby corn production. Indian Institute of vegetable research. Internet search. http://www.Agron.missouri.edu.

Lance, R.G.(2003). Agronomy 212- Grain and forage crops. Cobyright (C) 1998-99,2000-01 Iowa State University. All rights reserved. Revised: sept.26.

Lass,L.W., R.H.Callihan and D.O.Everson.(1993). Forecasting the harvest date and yield of sweet corn by complex regression models. J.Amer.Soc.Hort.Sci. 118(4):450-455.

Miles, C., L. Zenz, and G. Alleman. (1999). Baby corn. Food from the field series brochure, Washington State University Cooperative Extension King County, http:// agsyst.wsu.edu/cornbroc.htm.

Nelson, N. (1974). A photometric adaptation of Somogyi methods for Determination of glucose. J. Biology Chem., 159: 375 - 380 .

Nielsen, R.L.(2012). Heat unit concepts related to corn development. http:// www.agry.purdue.edu/Ext/corn/news/timeless/heatunits.html.

Oktem,A.(2004). Determination of sowing dates of sweet corn (Zea mays L.saccharata sturt.)under sanhufra conditions. 28.83-91.

Rahmani,A.,S.K.Khorasani and S.SM.Kalal.(2009). Effect of sowing date and plant density on morpho- phyaiological traits, yield and yield components of (baby corn) var. ksc 403su. J.Seed and plant 25- 2 (4): 449-463.

Rodov, V.,A.Copel, N.Aharoni,Y.Aharoni, A.Wiseblum,B.Horev and Y. Vinokur.(2000). Nested modified - atmosphere packages maintain quality of trimmed sweet corn during cold storage and the shelf life period. Postharvest Biol. Technol. $18: 259-266$.

Singh, R.D.and H.S. , Gupta. (2002). Effect of varieties and plant densities on yield, yield attributes and economics of babycorn (Zea mays). Indian Journal of Agronomy, v.47, n.2, p.221-226.

Snedecor, G. W. and W. G. Cochran (1981). Statistical methods. $6^{\text {th }}$ Iowa State Univ. Press, USA.

Somogyi, M. (1952).Notes on sugar determination, Jour. Biology Chem., 195: $19-23$.

Wang,Z., M.Stone and E.Gray. (2010). Effect of different scheduales of baby corn (Zea mays L.) harvests on baby corn yield. Grain yield and economic return. J.Kentucky Acad.Sci. 71: 59- 66.

Wills,R.B.G.,W.B.McGlasson,D.Grahum and D.C.Joyce(2007). Postharvest: an introduction to physiology and handling of fruits, vegetables and ornamentals. 5 th ed. CAB International, Wallingford,UK.

Fayoum J. Agric. Res. \& Dev., Vol. 30, No.1, January, 2016 
Shehata, S.A. et al.,

تأثير الهجين ومواعيد الزراعة و الحصاد على المحصول والجوده والقدرة التخزينيه لمحصول

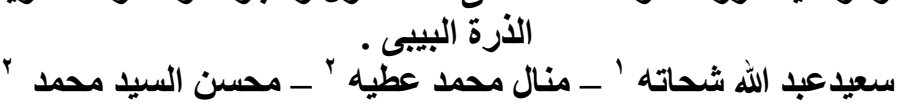

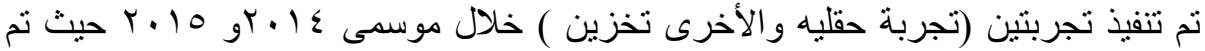

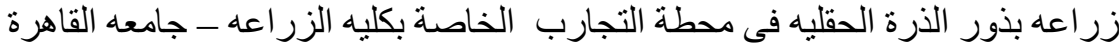

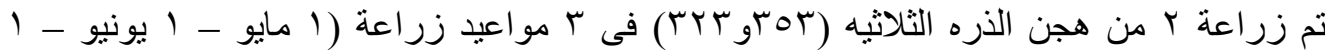

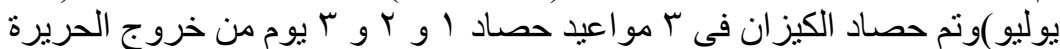

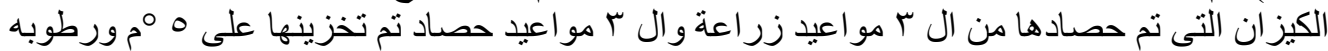

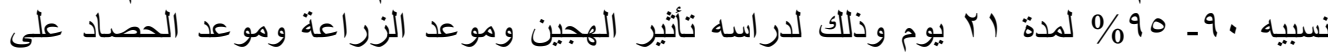

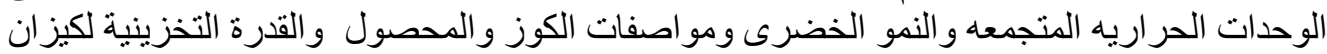

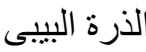

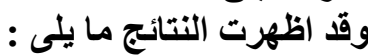

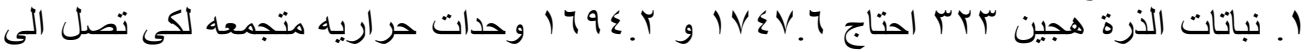

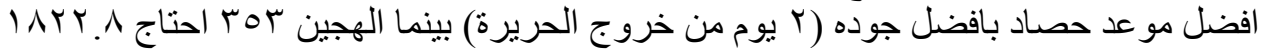

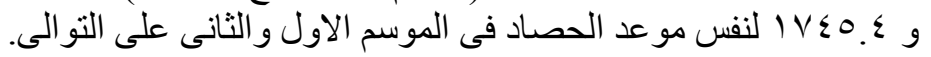

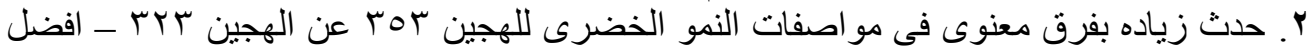

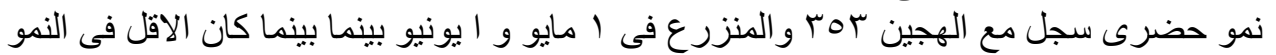

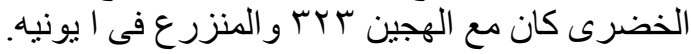

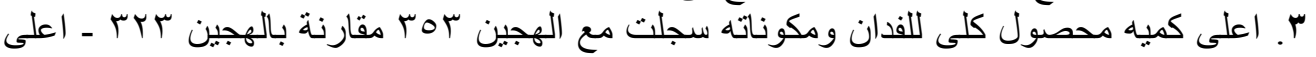

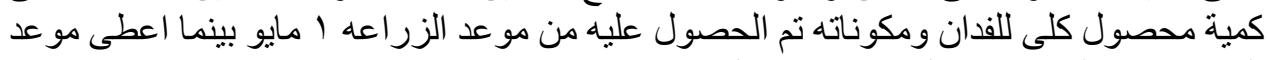

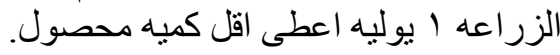

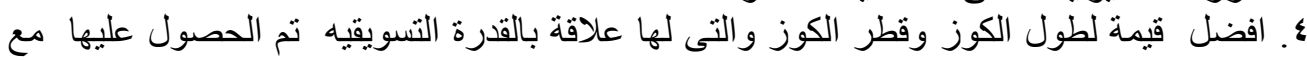

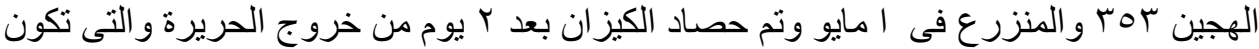

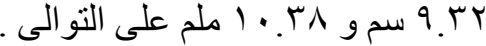

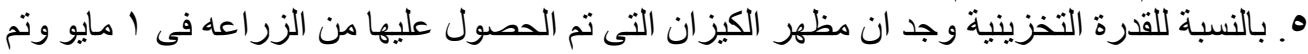

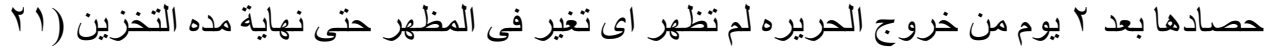

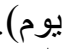

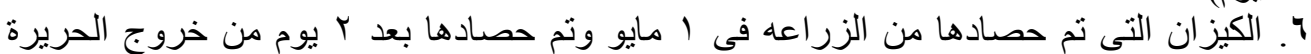

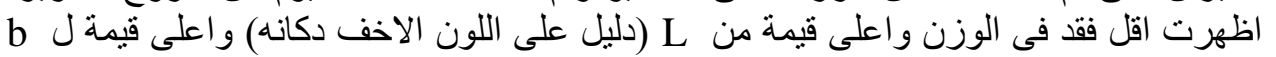

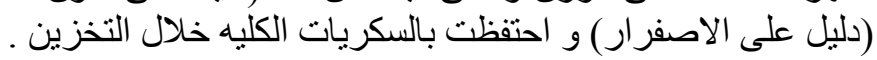

